\title{
A Study of the Winter Surface Ozone in Taipei
}

\author{
By Chung-Ming Liu \\ Department of Atmospheric Sciences, National Taiwin University, Taipei, Taiwan, R.O.C \\ and \\ Shaw C. Liu \\ Aeronomy Laboratory, NOAA/ERL, Boulder, Colorado, U.S.A. \\ (Submitted to the Journal of the Meteorological Society of Japan)
}

\begin{abstract}
In the Taipei basin in winter, surface ozone concentration usually displays a diurnal pattern with double peaks, one in the early morning, the other in early afternoon. The occurrence probability of double-peak days in a particular winter can be as high as $45 \%$. In this study, a field experiment is carried out to test a hypothesis proposed by the authors in a previous paper to explain the formation of the double peaks.

The field experiment shows that the double peak days tend to appear after the passage of a coldfront over northern Taiwan. At that time the Taipei basin is characterized by a strong northeasterly monsoon, low temperature, and overcasting sky with occasional light rain. An upstream hilltop ozone station shows that a background ozone of about $30 \mathrm{ppbv}$ is carried by the monsoon into the Taipei basin. Effective transport processes replenish the near surface ozone that is otherwise titrated out by vehicle-emitted nitrogen oxide (NO). The diurnal ozone double peaks occur at times when the NO concentration is at its minimum which are the result of the combined effect of diurnal traffic pattern and transport processes.
\end{abstract}

\section{Introduction}

A recent study of the surface ozone distribution in the Taipei basin (Fig. 1) (Liu et al., 1990) showed that a high level of ozone is a serious problem in Taipei. The study pointed out that the diurnal ozone variation in summer was mainly governed by a single-peak (SP) pattern with the peak near noontime. In winter, however, the diurnal ozone distribution was dominated by a double-peak (DP) pattern with a peak near noontime and another in the early morning.

The frequency of occurrence of the SP ozone is more than $50 \%$ in summer. An analysis of observed $\mathrm{NO}, \mathrm{NO}_{2}$ and $\mathrm{NMHC}$ data suggested that, as for other large cities, the photochemical production of ozone is responsible for the peak at noontime.

The DP has a greater than $45 \%$ probability of occurrence in winter. It appears simultaneously at all monitoring stations in the Taipei basin. Obviously, photochemical production processes can not be the cause of the early morning peak. Liu et al. (1990) proposed a hypothesis that a unique local circula- tion might be responsible for the occurrence of the double peak, and suggested an experiment to test it.

In the past, nocturnal ozone peaks have been observed by several groups (Kroening and Ney, 1962; Berry, 1964; Stasiuk and Coffey, 1974) and usually interpreted to be a result of breakdown of the noctournal inversion layer (Samson, 1978; Mizuno and Yoshikado, 1983). However, they did not occur with such high frequency (over $45 \%$ ) and regularity.

In this paper, the cause of the DP is studied by carrying out intensive observations of ozone and meteorological parameters during January and February, 1989 designed to test the proposed hypothesis of Liu et al. (1990). To facilitate later discussion, in the following section we summarize the hypothesis by discussing the meteorological environment believed to contribute to the formation of DP. The meteorological and surface ozone data collected during three Intensive Observation Periods (IOPs) are analyzed in Section 4. Finally, the conclusion and the summary of findings are presented in Section 5 .

(C)1991, Meteorological Society of Japan 


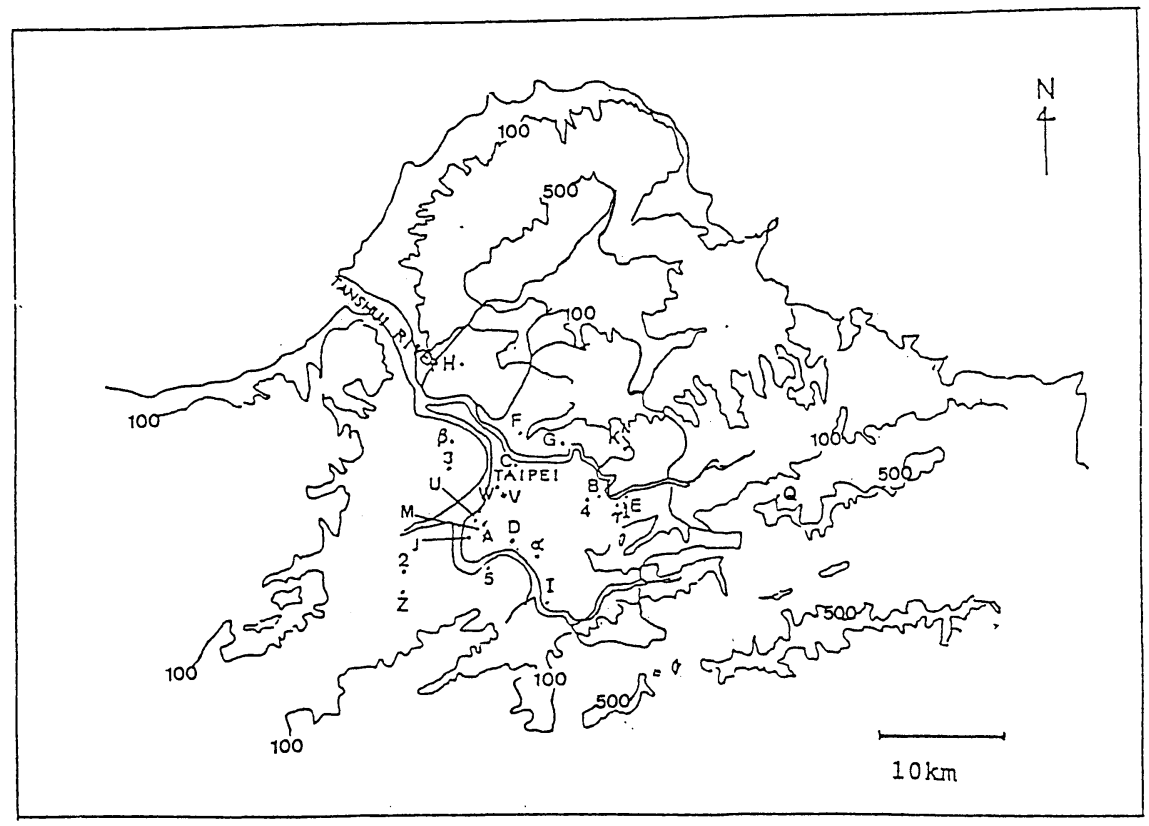

Fig. 1. The topography of northern Taiwan with contour lines of $100 \mathrm{~m}$ and $500 \mathrm{~m}$. The air quality monitoring stations 1-5 are operated by the Environmental Protection Administration (EPA), while stations A-W are operated by the Bureau of Environmental Protection (EPB) of Taipei City Government. Stations $\mathrm{M}$ and $\mathrm{Z}$ are the surface meteorological station and the atmospheric sounding station, respectively, and are operated by the Central Weather Bureau (CWB). Station M also monitors the surface ozone. During January and February, 1989, an upstream background ozone monitoring station was set up at station Q. While during a planned intensive observation period (IOP), three pibal stations $\alpha, \beta$ and $\gamma$ were chosen to measure the vertical wind field in the basin along with the intensive sounding observation at station $\mathrm{Z}$.

\section{The hypothesis}

The air quality monitoring stations operated by the Environmental Protection Administration (EPA), and the Bureau of Environmental Protection (EPB) are identified in Fig. 1. It can be seen that the Taipei basin is surrounded by hills except the Tanshui River outlet to the northwest, a valley to the northeast and a valley to the southwest. As we shall see in the following, this geographical structure is important to the formation of the DP. In Fig. 2 , the observed mean DP ozone diurnal distributions at the monitoring stations during January, 1987 are illustrated. The DP ozone occurs $47 \%$ in January, 1987, while the SP ozone occurs $20 \%$. The remaining $33 \%$ are days with low ozone amount throughout the day, i.e. the peak $\mathrm{O}_{3}$ being smaller than $20 \mathrm{ppb}$.

Meteorological parameters obeserved at the Taipei surface meteorological station, which is operated by the Central Weather Bureau (CWB) and marked as $\mathrm{M}$ in Fig. 1, indicate that on most DP days the cloud cover is greater than $80 \%$, implying a low photochemical production of ozone (Liu et al., 1990). Furthermore, on most DP days the prevailing wind is relatively strong $\left(>2 \mathrm{~m} \mathrm{~s}^{-1}\right)$ from the ENE direction with negligible diurnal variation, suggesting that the stagnant accumulation of surface ozone

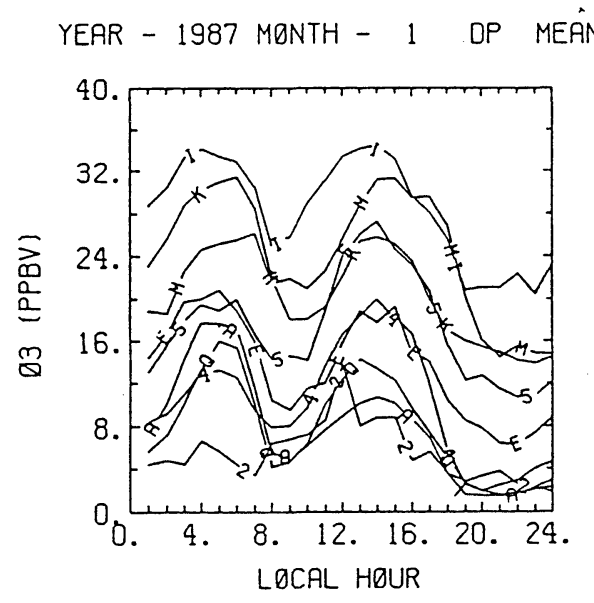

Fig. 2. The mean DP-days ozone observed by EPA and EPB stations (Fig. 1) during January, 1987.

is unlikely.

Based on the information available, Liu et al. (1990) proposed a hypothesis for the cause of the DP that can be described as follows. In winter, the cold air outbreak at mid-latitudes pushes a cold front over Taiwan, causing the surface temperature to drop by as much as $10^{\circ} \mathrm{C}$. Usually, the continental high behind the cold front is quite thin (lower 


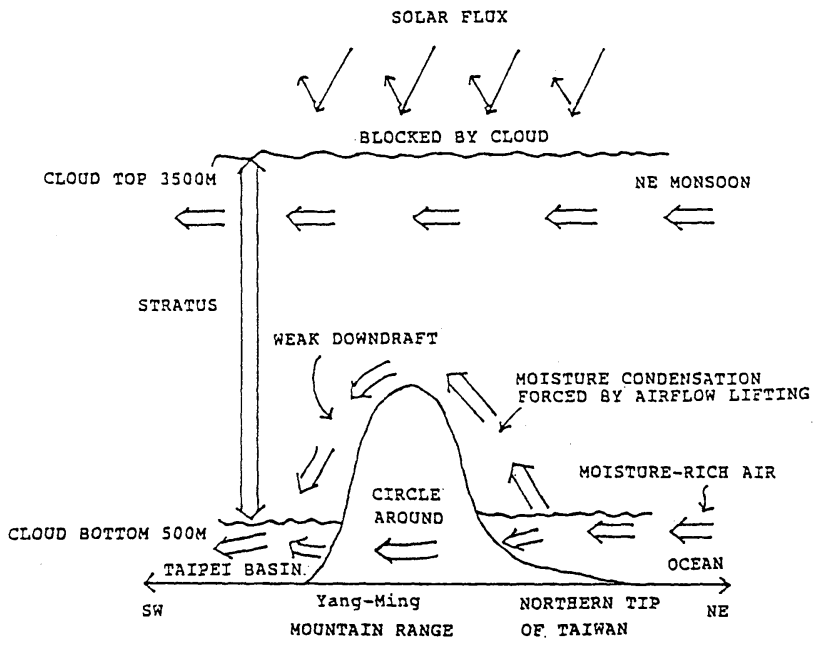

Fig. 3. The idealized air flow pattern and cloud formation in northern Taiwan during NE monsoon.

than $700 \mathrm{mb}$ ) and moves southeastward toward the Pacific. When the high pressure center is close to Japan, the prevailing wind in Taiwan is often coming from the NE and has been identified as the NE monsoon locally. Since a lot of moisture is brought along by the air flowing over the ocean, an overcast sky with light rainfall is often expected in northern Taiwan (Fig. 3). Usually, the overcast stratus cloud devolops below $700 \mathrm{mb}$ and sometimes reaches to $500 \mathrm{~m}$ above the ground, which is thick enough to block solar radiation and prevent effient photochemical production of ozone below the cloud. As will be shown later, in these circumstances, a 4-day back trajectory analysis usually can trace back to northeastern China. Hence, it was proposed that the surface ozone observed in Taipei is probably transported from an upstream source and from a higher altitude. The level of ozone is controlled by this transport process and the titration by $\mathrm{NO}$ emitted from automobiles, i.e. $\mathrm{NO}+\mathrm{O}_{3} \rightarrow \mathrm{NO}_{2}+\mathrm{O}_{2}$, By examining the observed diurnal distribution of $\mathrm{NO}$, Liu et al. (1990) proposed that the double peaks of ozone were primarily the result of low traffic density. As we shall see later, While the early morning peak of ozone is indeed caused by low traffic density, the early afternoon peak is primarily the result of enhanced transport of ozone from the upstream source.

\section{Intensive observations}

In order to test the proposed hypothesis, a series of intensive observations of ozone and meteorological parameters were carried out during January and February, 1989. To observe the ozone concentrations upstream of the Taipei basin, an ozone monitoring station was set up at $500 \mathrm{~m}$ altitude northeast of the basin (marked as Q in Fig. 1). This site is lo- cated approximately at the highest point in near-by mountains where no local pollution source exists. Without titration by NO, higher ozone concentrations than in the basin are expected at the site during DP days.

Three pibal stations ( $\alpha, \beta$, and $\gamma$ in Fig. 1$)$ and a sounding station ( $\mathrm{Z}$ in Fig. 1) were selected. This enabled intensive observation of wind and temperature fields (every $3 \mathrm{hrs}$ ) during selected periods. The intensive observation period (IOP) was chosen based on the forecasting data in the expectation of a coldair outbreak and the passage of an NE monsoon. A total of three IOPs were selected and analyzed. They are discussed in the next section.

\section{The analysis}

Intensive observations were performed during three IOPs: IOPl (1/24 $11 \mathrm{am}-1 / 268 \mathrm{am})$; IOP2 (1/27 $11 \mathrm{am}-1 / 308 \mathrm{am})$; and IOP3 (2/1 $14 \mathrm{pm}-2 / 3$ $11 \mathrm{am})$.

\subsection{General Synoptic Condition}

A cold front passed over Taiwan on Jan. 22 and 23 , and caused the surface temperature to drop by $7^{\circ} \mathrm{C}$ (Fig. 4a) in Taipei. The surface wind direction changed gradually from NW to ENE (Fig. 4b), and the average wind speed increased from about $2 \mathrm{~m} / \mathrm{s}$ to $4 \mathrm{~m} / \mathrm{s}$ (Fig. 4c). Light rainfall occurred briefly in the early morning of Jan. 23. On Jan. 24 and 25, the high pressure centered over mid-China moved quickly eastward, resulting in an increase of the surface temperature. On the $25 \mathrm{th}$, the sky cleared and a localized sea breeze from the NW with lower wind speed occurred in the daytime. However, another cold front formed at midnight of the 25th near Taiwan, and a cold-air system over China moved consistently southward which resulted in a steady drop of the surface temperature by $13^{\circ} \mathrm{C}$ until the 28th. The first IOP was selected from $1 / 2411 \mathrm{am}-1 / 268$ am.

On the 27th a high pressure system with center pressure $1051 \mathrm{mb}$ over China moved gradually southward and eastward. After the 28th. this high pressure system moved toward Japan and led to a warming in Taipei (Fig. 4a). During the whole period, the NE monsoon prevailed over Taiwan, while the ENE wind with a wind speed between 2 and 7 $\mathrm{m} / \mathrm{s}$ was observed in Taipei from the 26 th to 30 th (Figs. 4b, c). Overcast persisted until the 29th with a light precipitation of maximum rate $0.8 \mathrm{~mm} / \mathrm{hr}$ on the 28th. The second IOP was chosen from 1/27 11 am to $1 / 308$ am.

On the 31st a cold air-mass originated from northern China pushed a cold-front over Taiwan at midnight. This high pressure system moved steadily southeastward until the 3rd of February when the system decoupled into two highs with one moving toward Japan and the other toward southern China. 
FROM 1.21 TO 2.3

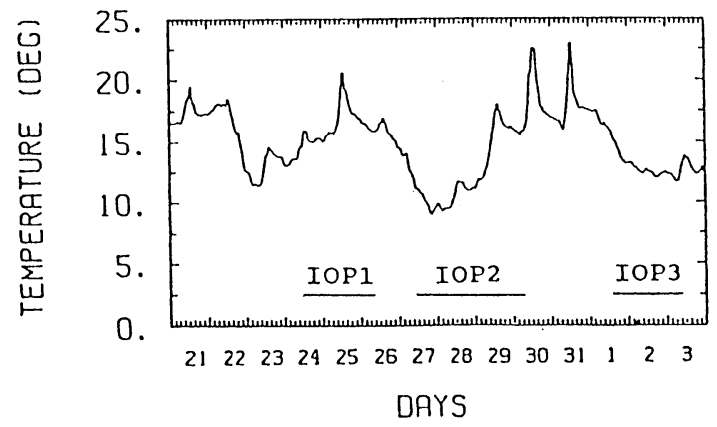

(a)

FROM 1.21 TO 2. 3
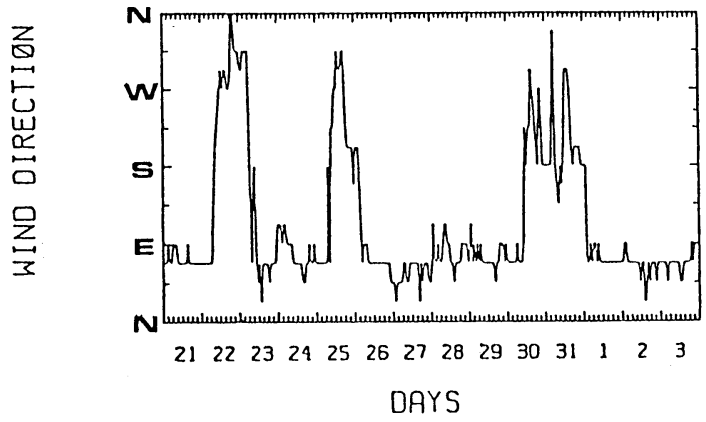

(b)

FROM 1.21 TO 2. 3
10.

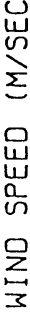

0 .

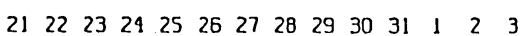

DAYS

(c)

Fig. 4. (a) Temperature, (b) wind direction and (c) wind speed observed at station $M$. during $1 / 21-2 / 3,1989$. The dated number points are for noon of that day.

This event of cold-air outbreak drove the surface temperature in Taipei down by $10^{\circ} \mathrm{C}$ from $1 / 31$ to $2 / 1$, while a persistent easterly wind with a strong windspeed of 3 to $6 \mathrm{~m} / \mathrm{s}$ was observed (Fig. 4). Meanwhile, Taipei was $100 \%$ overcast. The third IOP was from $2 / 114 \mathrm{pm}$ to $2 / 311 \mathrm{am}$.

\subsection{The Surface Ozone}

During IOP1, due to the high pressure system moving quickly eastward, the NE air-flow did not stay as long as expected. As a result, the mete-
YEAR - 1989 MONTH/DAY 1/21 - 2/3

(a)

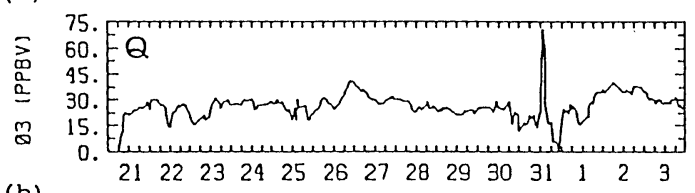

(b)
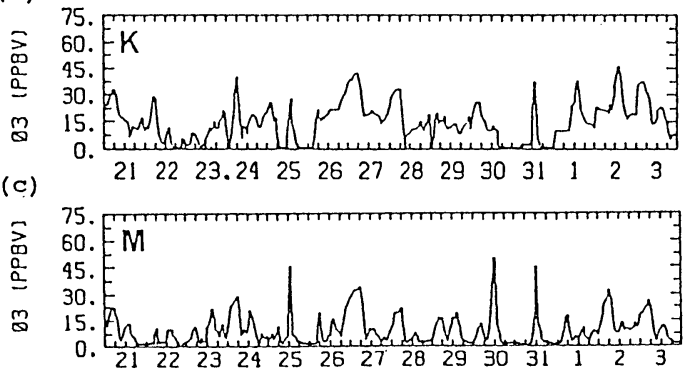

(d)

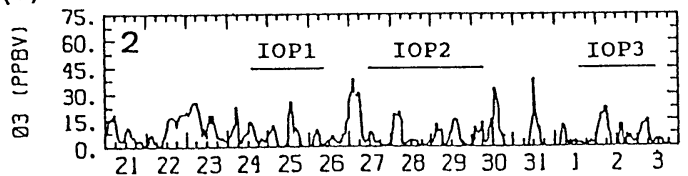

DAYS

Fig. 5. Surface ozone observed at station (a) $\mathrm{Q}$, (b) K, (c) $\mathrm{M}$ and (d) 2, during $1 / 21-$ $2 / 3,1989$. The dated number points are for noon of that day.

orological environment on the 25th and 26th did not fully meet the DP criteria. However, the surface ozone distribution showed some encouraging features. First, during the passage of the coldfront on the 22nd and 23rd the background ozone (Fig. 5a) started to increase by about $20 \mathrm{ppb}$ to around $33 \mathrm{ppb}$ where it stayed essentially constant with negligible diurnal variation until the 25th. A similar phenomenon occured on the 26th when a cold front formed near Taiwan. However the ozone first increased from $22 \mathrm{ppb}$ to $45 \mathrm{ppb}$ and then dropped back to around 30 ppb where it stayed unchanged. Meanwhile, downstream at stations K, M, and 2 (Fig. 1) a double-peak ozone pattern (Fig. 5) with peak ozone values smaller than the background ozone values were observed to occur simultaneously at these stations on the 24th. Other air-quality monitoring stations in the Taipei basin observed similar features, i.e. these three stations are representative of the ozone distributions in Taipei. In order to minimize the number of figures, only data at these three stations are plotted.

During IOP2, the prevailing NE monsoon with high wind speed met the DP criteria described in Section 2. The upstream background ozone remained around $30 \mathrm{ppb}$ after the 27 th with negligible diurnal change (Fig. 5), while stations downstream in the basin observed double-peaked ozone 
for all four days with the peak values in general smaller than the background ozone. In the daytime of the 31st, strong solar insolation led to a typical single-peaked ozone pattern at all monitoring stations. This single-peaked ozone is most likely to be photochemically produced because the peak values are significantly greater than the prevailing background value of $30 \mathrm{ppbv}$. It is interesting to note that the ozone concentration at the background site is again higher than values observed by stations in the basin despite the substantially higher concentrations of ozone precursors in the basin. This suggests that the outskirts of Taipei may have a more serious ozone problem during photochemical smog episodes.

IOP2 was the best case among three IOPs with regard to persistent DP ozone and the NE monsoon. In Section 4.3, a detailed analysis of the meteorological parameters of IOP2 will be made to study the evolution of DP.

During IOP3, the upstream background ozone increased after the passage of cold-front starting at noontime of $2 / 1$ until $2 / 2$. After that, negligible variation was dectected (Fig. 5). Downstream in the Taipei basin, DP ozone again occurred at all stations with ozone peaks in general smaller than the background ozone.

IOP3 also qualifies as a good case with prevailing NE monsoon and DP ozone. However, some logistic problems forced us to stop the operation before the conclusion of the cold-air outbreak event.

\subsection{The Local Meteorological Environment}

In this section, the meteorological environment during IOP2 $(1 / 2711 \mathrm{am}-1 / 308 \mathrm{am})$ is analyzed to investigate the air flow structure associated with the DP ozone.

The NE monsoon persisted from $1 / 27$ to $1 / 29$ along the plain to the northwest side of the Central Mountain Range which runs in the north-south direction and dominates the topograph of Taiwan. However, the airflow was forced to circle around the YangMing mountain which is located to the north of Taipai basin and has peaks over $500 \mathrm{~m}$ altitude. Figure 6 illustrates the situation on $1 / 28$. As a result, the surface wind observed at Taipei station (located near the center of basin) was mostly ENE or E. Meanwhile, uplifting of moisture-riched air by the YangMing mountain caused the formation of thick stratus cloud developing from $500 \mathrm{~m}$ height up to 1500-3500 m, and light rainfall. Under the lee side of the YangMing Mountain, a weak downdraft at the center of basin was expected (Fig. 3).

The vertical profiles of wind field observed at three pibal stations and the sounding station showed that below the cloud base strong $\mathrm{NE}$ or $\mathrm{E}$ wind prevailed throughout the IOP with wind speed decreasing toward the surface, e.g. at 1/28, 11 am (Fig. 7). A weak convergence of air flow in the
$1 / 28 \quad 8 \mathrm{am}$

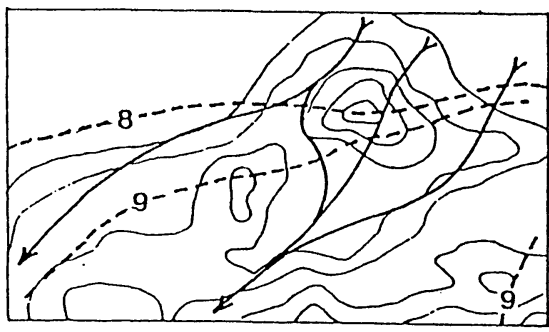

(a)

$1 / 28 \quad 8 \mathrm{pm}$

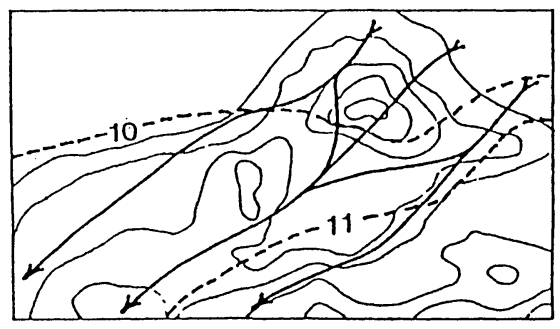

(b)

Fig. 6. The streamline (solid line) and isothermal line (dashed line, ${ }^{\circ} \mathrm{C}$ ) over northern Taiwan on $1 / 28$ (a) 8 am and (b) 8 pm.

basin below $500 \mathrm{~m}$ altitude was noted, consistent with the expected weak downdraft (Fig. 3). The intensive sounding observation downstream at PangChou station (marked as Z in Fig. 1) showed a windshear line above $2000 \mathrm{~m}$ height where the potential temperature converged and an inversion layer existed. Below this frontal zone, friction-forced mixing maintained a pseudo-moist-adiabatic neutral state. Thick stratus was distinguishable above $500 \mathrm{~m}$ up to 1500-3500 m height, if areas with above $80 \%$ relative humidity were assumed to be cloud areas. The global solar flux data measured at the Taipei station showed low solar insolation which was about 50 $\%$ below normal. Hence, the photochemical production of ozone was not effective.

The relatively strong wind velocity and neutral vertical temperature structure below $2000 \mathrm{~m}$ is conducive to both horizontal and vertical transport of ozone from an upstream point down to the surface station in the basin. With the NO concentration around $30 \mathrm{ppbv}$ in early morning at the stations in the basin, the lifetime of ozone is only about 2 minutes against titration by NO. Obviously, horizontal or vertical transport of ozone is essential for the formation of the ozone maximum in early morning. This transport process probably also contributes significantly to the formation of the ozone peak near noontime during the DP day.

In contrast, the horizontal wind velocity in a typ- 


\section{$1 / 28 \quad 11 \mathrm{am} \quad 100 \mathrm{~m}$}

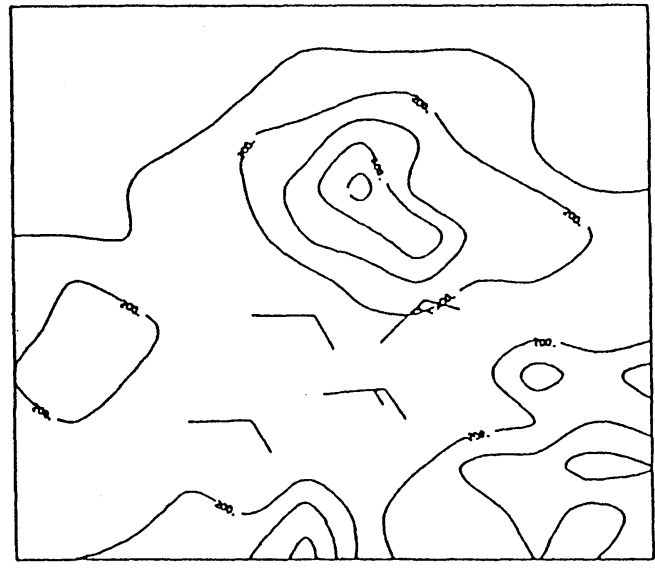

(a)

\section{$1 / 28 \quad 11 \mathrm{am} \quad 300 \mathrm{~m}$}

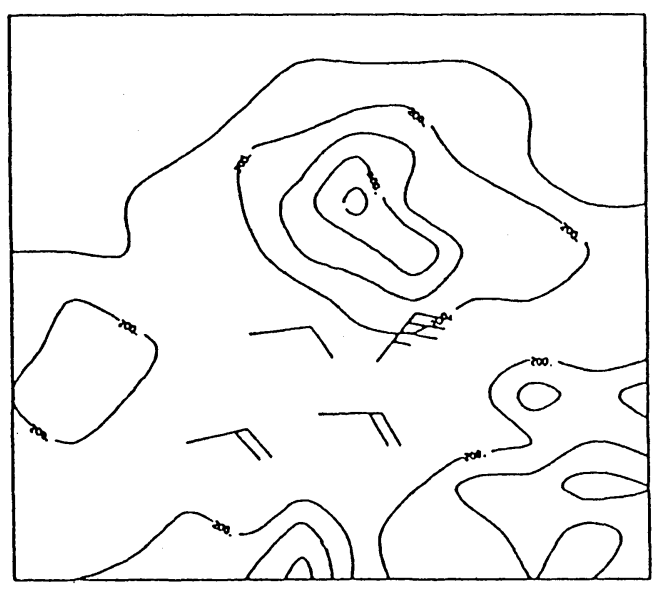

(b)

\section{$1 / 28 \quad 11 \mathrm{am} \quad 500 \mathrm{~m}$}

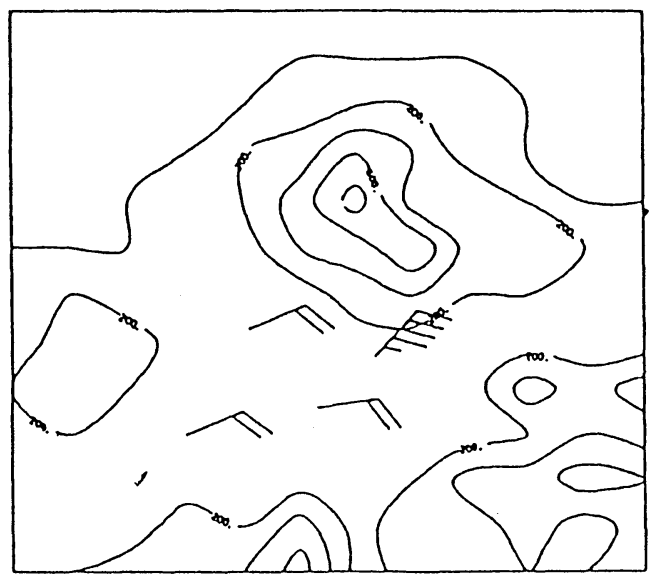

(c)

Fig. 7. The wind field observed at stations $\alpha$, $\beta, \gamma$ and $\mathrm{Z}$ at (a) $100 \mathrm{~m}$, (b) $300 \mathrm{~m}$ and (c) $500 \mathrm{~m}$ height at $11 \mathrm{am}, 1 / 28,1989$. ical SP day (e.g. the 25th) is $1 \mathrm{~m} / \mathrm{s}$ or less (Fig. 4c). This is consistent with the analysis of summertime SP cases by Liu et al. (1990). In addition, the SP day is characterized by clear sky conditions that usually lead to the formation of a nocturnal inversion and effectively curtail the vertical transport. This is clearly demonstrated by the relatively large vertical gradient of potential temperature at site Z (Fig. 1) in the early morning of the 25th (Fig. 8a) compared to a typical DP day (the 28th, Fig. $8 \mathrm{~b}$ ). Without efficient vertical and horizontal transport, surface ozone in the Taipei basin is quickly titrated out in early morning. The single peak of the SP day near noon time is most likely produced by photochemical reactions.

\subsection{Back Trajectcry Analysis}

Since the potential temperature, $\Theta$, is a conserved quantity for adiabatic motion. Lagrangian tracing of an air parcel is usually done on an isentropic surface. In this study the isentropic surface of $\Theta_{s}$, which occurred below $850 \mathrm{mb}$ at station $\mathrm{Z}$ on DP days, was chosen for back trajectory analysis from northern Taiwan for four days, so as to identify the location of the upstream source.

The air parcel trajectory obtained for IOP-1 (Fig. 9a) shows that the upstream source originated near $35^{\circ} \mathrm{N}, 115^{\circ} \mathrm{E}$ at an altitude of about $2000-2400 \mathrm{~m}$. The air parcel moved first slowly southeastward to the Pacific, and then swiftly southward to Taiwan, which can be related to the passage of a cold front on $1 / 22-23$.

Similar air parcel movement pattern was also found for IOP-2. However, the upstream source was around $37.5^{\circ} \mathrm{N}, 120^{\circ} \mathrm{E}$, at $2200 \mathrm{~m}$. By tracing further back for another three days (Fig. 9b), the source can be traced to $45^{\circ} \mathrm{N}, 105^{\circ} \mathrm{E}$, at $3600 \mathrm{~m}$. Similar air parcel movement was also derived for IOP-3.

In all three cases, the back trajectory analysis on an isentropic surface suggests that an upstream mainland high-level air parcel first moves SE or E toward the Pacific, then directly southward to northern Taiwan. Such an air parcel movement is consistent with the evolution of a continental cold-air outbreak (Palmen and Newton, 1951).

\subsection{The analysis of DP Ozone field}

Between $1 / 16$ and $2 / 28$ when the background ozone observation was available, six cold fronts passed by Taiwan on $1 / 23,1 / 25,1 / 31,2 / 8,2 / 18$ and $2 / 24$, which were identified by a significant drop of surface pressure and temperature. After the passage of each cold front, the ozone observed at the background station upstream of Taipei started to increase by about $13 \mathrm{ppb}$ (Table 1), and reached a maximum when the NE wind established itself. From then on, the background ozone maintained a steady level with negligible diurnal variation. Under these conditions, a double-peaked diurnal ozone 


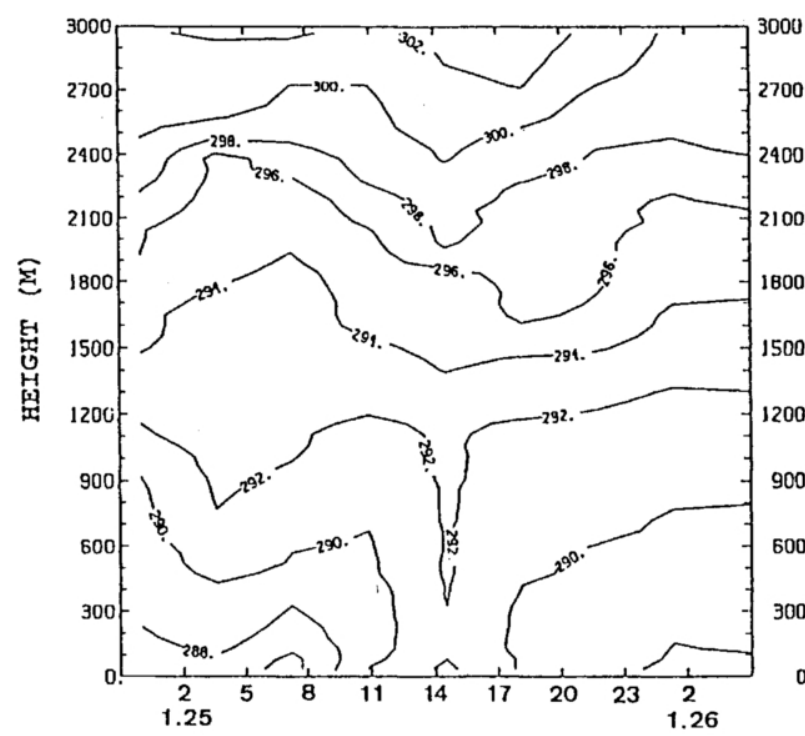

(a) potential temperature

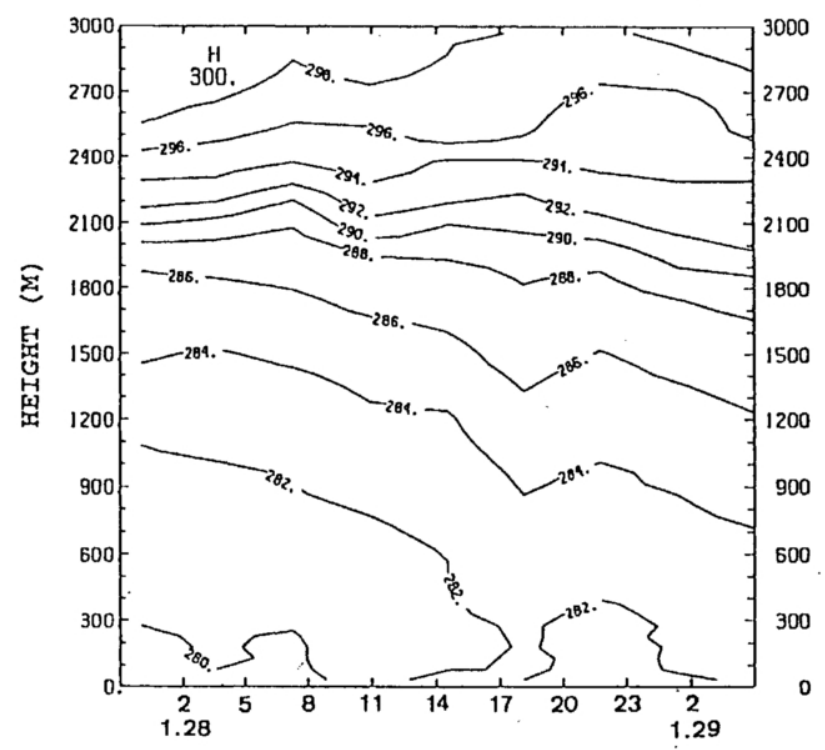

(b) potential temperature

Fig. 8. The temporal variation of the vertical profile of potential temperature at site Z, on (a) $1 / 25$ and (b) $1 / 28,1989$.

pattern was usually observed in the downstream basin stations, with all peak values smaller than the background ozone.

Between $1 / 16$ and $2 / 28,63 \%$ were days with double-peaked ozone (all DP-days). The mean diurnal variations of $\mathrm{O}_{3}, \mathrm{NO}$ and $\mathrm{NO}_{2}$ of these DP-days are plotted in Fig. 10. The mean background ozone was around $30 \mathrm{ppb}$ (Fig. 10a). The stations in the basin had ozone peaks at around 5-6 am and 13-14 $\mathrm{pm}$, with the morning peak in general larger than the afternoon peak (Fig. 10a). Low ozone occurred (a)

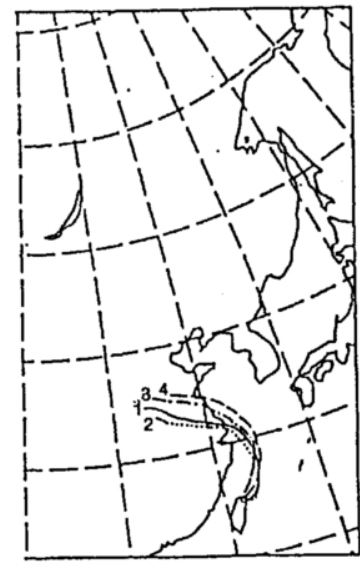

1: $1 / 20$ 8am - 1/24 8am

2: $1 / 20$ 20pa - $1 / 24$ 20pm

4: $1 / 21$ 8am $-1 / 25$ 8am (b)

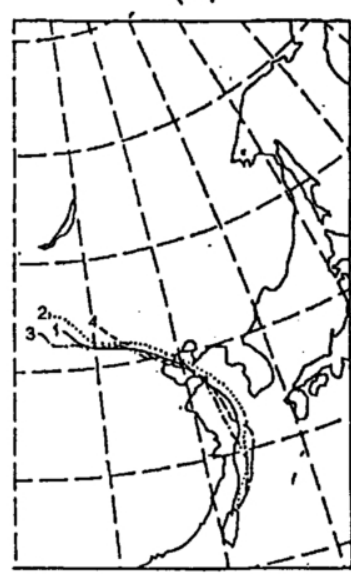
2.: $1 / 2020 \mathrm{pm}-1 / 2720 \mathrm{pm}$ 3.: $1 / 20$ 8am - 1/28 8pm 4: $1 / 2020 \mathrm{pm}-1 / 2820 \mathrm{pm}$
1: $1 / 20$ 8am - $1 / 27$ 8am

Fig. 9. The four-day back trajectories of air parcel on an isentropic surface during (a) IOP-1 and (b) IOP-2 (for seven days).

Table 1. Observed increases in background ozone mixing ratio after the passage of cold fronts.

$\begin{array}{lcc}\text { date } & \begin{array}{c}\text { from } \\ (\mathrm{ppb})\end{array} & \text { to } \\ 1 / 23 & 20 & 23 \\ 1 / 26 & 20 & 45 \\ 2 / 1 & 15 & 40 \\ 2 / 8 & 5 & 30 \\ 2 / 18 & 5 & 20 \\ 2 / 24 & 9 & 23\end{array}$

at about 8-10 am and 19-24 pm. As expected, Fig. $10 \mathrm{~b}$ shows that the average diurnal NO concentrations were directly anticorrelated with those of ozone. As discussed earlier, the negative correlation between $\mathrm{O}_{3}$ and $\mathrm{NO}$ can be explained by the reaction $\mathrm{NO}+\mathrm{O}_{3} \rightarrow \mathrm{NO}_{2}+\mathrm{O}_{2}$. The absolute value of the correlation coeffiecient between $\mathrm{NO}$ and $\mathrm{O}_{3}$ during all DP-days (Table 2) is greater than 0.528, while the coefficient between the mean DP-day hourly data can reach up to 0.949 .

The minimum of NO concentration in the early morning (Fig. 10b) is clearly due to the light traffic at that time. The cause of the noontime NO minimum is more complicated. The observed traffic pattern in Taipei shows only a slight decrease at that time. We believe that the dilution effect due to transport processes plays a major role in determining the noontime NO minimum. This is substantiated by the high noontime horizontal wind velocity (at site M, Fig. 4c) as well as the noontime minimum vertical gradient of potential temperature (at site $\mathrm{Z}$, Fig. 8b). 


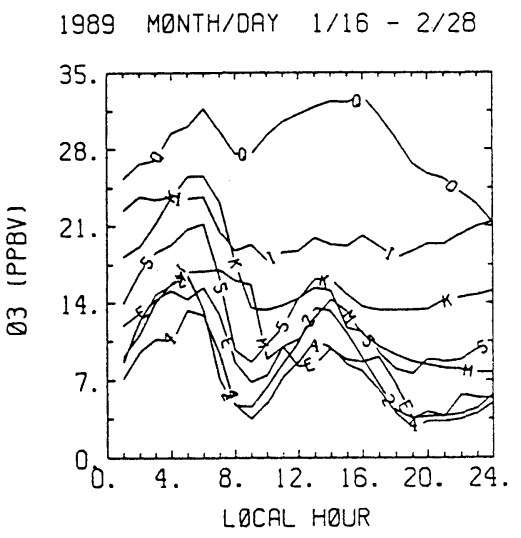

(a)

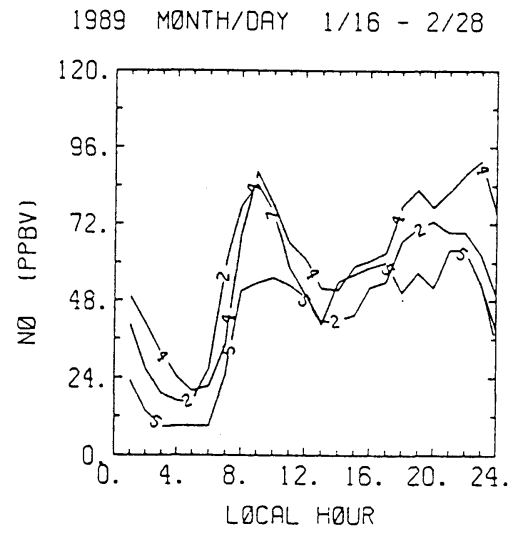

(b)

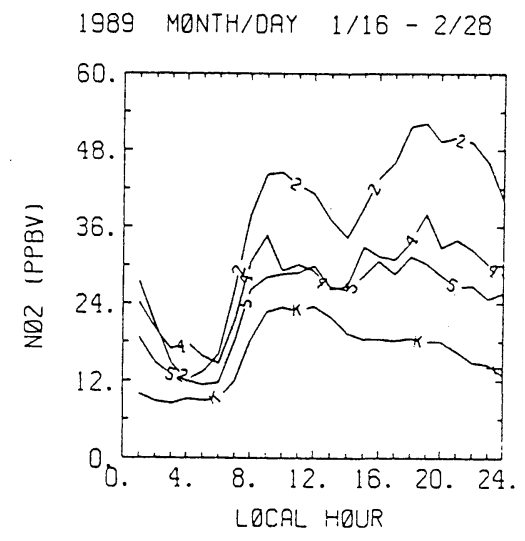

(c)

Fig. 10. The averaged mixing ratios of all DP-days for (a) ozone, (b) $\mathrm{NO}$ and (c) $\mathrm{NO}_{2}$ observed during $1 / 16-2 / 28,1989$.

Table 2. Correlation coefficients between NO and $\mathrm{O}_{3}$ for all DP-days during $1 / 16-2 / 28$, 1989 , and for the averaged diurnal distributions of all DP-days (the mean DP-day).

$\begin{array}{cll} & \text { all } & \text { mean } \\ \text { station } & \text { DP-days } & \text { DP-day } \\ 2 & -0.623 & -0.949 \\ 4 & -0.556 & -0.931 \\ 5 & -0.528 & -0.894\end{array}$

Observed diurnal variations of $\mathrm{NO}_{2}$ are also consistent with the notion that ozone is titrated by NO. Figure 10c shows two peaks of $\mathrm{NO}_{2}$, one near 10:00 and the other around 19:00, both coincide with the two diurnal minima of ozone. Quantitatively, the diurnal variations of $\mathrm{NO}_{2}$ are expected to be equal to those of ozone. However, the variations of $\mathrm{NO}_{2}$ are about $50 \%$ greater. This is probably the result of the $\mathrm{NO}_{2}$ measurement technique which is based on heated chemical conversion and also converts other reactive nitrogen species to NO (Fehsenfeld et al., 1987). Of course, it is also possible that there is a calibration problem with the $\mathrm{NO}_{2}$ measurements. In any case, the strong anti-correlation between $\mathrm{NO}_{2}$ and ozone strongly supports our hypothesis.

\section{Summary and conclusion}

We have designed and carried out three intensive observations of ozone and meteorological parameters to test a hypothesis by Liu et al. (1990) on the formation of the winter double-peak diurnal ozone distribution in the Taipei basin.

The four-day back trajectory analyses for typical double-peak days show that ozone originally located at $2-3 \mathrm{~km}$ over northern China is transported first southeastward to the Pacific then southward to northern Taiwan by a cold-air high pressure system after the mid-latitude cold-air outbreak. After the passage of the cold front, the Taipei basin is characterized by a strong northeasterly wind, cold temperature, and overcast sky with occasional light rain. Measurements at a hill site (about $500 \mathrm{~m}$ height) upstream of the Taipei basin show that after each passage of a cold front, the background ozone increases to about $30 \mathrm{ppb}$ with negligible diurnal variation. Air carrying the background ozone is driven southeastward and downward into the Taipei basin by strong horizontal and vertical transport processes that effectively replenish the near-surface ozone that is otherwise titrated out by vehicle-emitted NO. The diurnal variation of $\mathrm{NO}_{2}$ is also consistent with this notion. This is substantiated by the close inverse correlation observed between the diurnal variations of ozone and NO. The early morning ozone peak is the result of the horizontal or vertical transport of ozone and the low NO emission due to light traffic, and the late morning ozone minimum is caused by the high NO emission due to the heavy traffic, consistent with the hypothesis of Liu et al. (1990). However, the early afternoon ozone peak and NO minimum is caused primarily by increased vertical and horizontal transport, as evidenced by the diurnal variations of the vertical structure of the potential temperature and the wind velocity.

\section{Acknowledgement}

This study was funded by the Environmental Protection Administration of the Republic of China under grant EPA-78-002-10-069. The authors want to express their sincere gratitude to the Bureau of Environmental Protection of the Taipei City Government and the Central Weather Bureau for providing data and help during the work of this paper. 


\section{References}

Berry, C.R., 1964: Differences in concentrations of surface oxidant between valley and mountain top conditions in the southern Appialachians. J. Air Pollut. Control Asso., 14, 238-239.

Fehsenfeld, F.C., R.R. Dickerson, G. Hubler, W.T. Luke, L.J. Nunnermacker, E.J. Williams, J.M. Roberts, J.G. Calvert, C.M. Curran, A.C. Delany, C.S. Eubank, D.W. Fahey, A. Fried, B.W. Grandrud, A.O. Langford, P.C. Murphy, R.B. Norton, K.E. Pickering and B.A. Ridley, 1987: A groundbased intercomparision of NO, NOx, NOy measurement techniques. J. Geophys. Res., 92, 14710-14722.

Kroening J.L. and Ney E.P., 1962: Atmospheric ozone. J. Geophys. Res., 67, 1867-1875.
Liu, C.M., S.C. Liu, and S.H. Shen, 1990: The study of Taipei ozone pollution. Atmos. Environ., 24a, 14611472.

Mizuno, T. and H. Yoshikado, 1983: On some characteristics of the diurnal variation of $\mathrm{O}_{3}$ observed in island, urban and rural areas. Atmos. Environ, 17, 2575-2582.

Palmen, E. and Newton, C.W., 1951: On the threedimensional motions in an outbreak of polar air. $J$. Meteor., 6, 227-242.

Samson, P.J., 1978: Nocturnal ozone maxima. Atmos. Environment, 12, 951-953.

Stasiuk, W.N. and Coffey P.E., 1974: Rurai and urban ozone relationships in New York State. J. Air. Pollut. Control. Ass., 24, 564-568.

\section{台北における冬期の地表オゾンの研究 \\ 柳 中明 \\ (国立台湾大学大気科学部)}

劉 紹臣

( NOAA Aeronomy Laboratory)

冬期の台北の盆地において地表オゾン濃度は通常、早朝と午後の早い時刻に 2 つの極大をもつ。特定の 冬では 2 つ極大をもつ確立は $45 \%$ にのぼる。ここでは以前の研究で著者により提案された 2 つ極大を 説明する仮説を試すために野外実験を行った。野外実験の結果、2つの極大は台湾の北を寒冷前線が通過 した後起こり易いことが分かった。この時、台北盈地は強い北東風の季節風、低温、少しの雨を伴う雲天

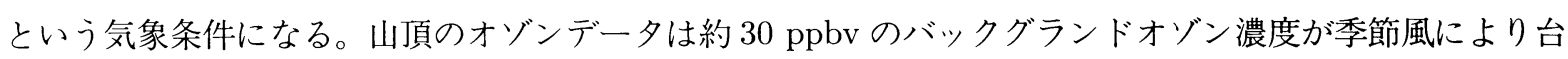
北盆地にもたらされることを示している。自動車から放出される一酸化窒素（NO）の影響でオゾンが失 われるが、この効率的な輸送が新たなオゾンを供給する。オゾンの 2 つの極大は NO 濃度が極小になる時 起こる。これは交通量の日変化と輸送過程の重なり合った効果により起こる。 